\title{
Laste mäng ja kujutlusvõime
}

\author{
Kirill Maslov ${ }^{1}$
}

\section{Võgotski, L. (2016). Laste loovus ja kujutlusvõime. Mäng ja selle osa lapse psüühilises arengus. Tallinn: Tallinna Ülikooli Kirjastus.}

Lapsepsühholoogia on tõeliselt ammendamatu teema ja pole mõtet otsida põhjusi, miks laste käitumine ja areng pakuvad huvi nii suurele hulgale teadlastest. Lev Võgotskist (1896-1934) on kujunenud psühholoogiaklassik, tema töödeta on raske ette kujutada tänapäevast psühholoogiateadust. Esitletav raamat koosneb kahest Võgotski tööst, mille aineseks on lapse kujutlusvõime ja mäng.

Brošüür „Laste loovus ja kujutlusvõime“ nägi ilmavalgust 1930. aastal, teine trükk avaldati alles 1967. aastal. Aasta varem ehk 1966 ilmus ajakirjas Voprosõ Psihologii Võgotski artikkel „Mäng ja selle osa lapse psüühilises arengus“. Seetõttu on lugejal õigus küsida, miks on vaja tõlkida ja trükkida teoseid, mis on ilmunud aastakümneid tagasi - teadus ei seisa ju paigal. Seejuures võib niisugust kriitikat oodata nii hallipäiselt torisevalt kultuuripsühholoogiaprofessorilt kui ka praktikult, kelle igapäevane elu ja töö on seotud laste kasvatamisega. Siinses artiklis püütakse neid põhjusi selgitada.

Tutvustatava raamatu ilmumine on seotud mitmesuguste asjaoludega. Esiteks, lapsepsühholoogia on risti-põiki läbi uuritud teaduslik sound ja Võgotski töödel on selles täita märkimisväärne osa: need moodustavad sõlmkoha või verstaposti, mille tundmine on kohustuslik neile, kes tegelevad psühholoogiaga. Teine põhjus seisneb selles, et kuulsa klassiku ideed ja ettepanekud ei ole kaotanud oma tähtsust ka tänapäeval. Populaarteaduslikul viisil suudab autor rääkida sügavatel teemadel ning teha seda üsna loovalt ja huvitavalt - nii loovalt, et mitte iga hallipäine kogenud ja tõsimeelne teadur poleks selleks võimeline. Seejuures tuleb kindlasti arvesse võtta, et need Võgotski tööd olid mõeldud laiemale publikule. Pealegi oli Lev Võgotski ka suurepärane lektor, kes kihutas pidevalt mööda maad ringi, pidades loenguid nii Moskvas kui ka Leningradis Herzeni-nimelises instituudis (selles õppeasutuses pidaski Võgotski 1933. aastal oma loengu lapse mängust). Kolmas põhjus võib olla veidi naiivne, aga seda

Tallinna Ülikooli psühholoogiadoktor (2012), erivajadusega isikute peaspetsialist Maardu Linnavalitsuses. 
tuleb siiski mainida: mul on väga hea meel, et peale vene psühholoogide on maailma suurimad Võgotski propageerijad Eesti psühholoogid. Näiteks on Jaan Valsineri raamat „Understanding Vygotsky: A quest for synthesis“ (1991; kaasautor R. van der Veer) Võgotski üks parimatest teadusbiograafiatest. Samuti on eesti psühholoogia korüfee Peeter Tulviste (1945-2017) tõlkinud eesti keelde Võgotski monumentaalse töö „Mõtlemine ja kõne“ (2014). Seega, 2016. aastal laste loovuse ja mängu kohta raamatu ilmumine ei ole juhuslik, vaid pigem seaduspärane ning on väga rõõmustav, et eestikeelne lugeja (nii teoreetik kui ka vaeva nägev praktik) on saanud endale abivahendi, mis rikastab tema tööd.

Milles seisneb siin tutvustatava raamatu väärtus? Võgotski on korjanud kokku rikkaliku faktilise andmestiku, mida on pakkunud teised tema ajastu teadlased. Nende andmete tõlgendusele tuginedes on ta esitanud lugejaskonnale oma originaalse arusaama, lähtudes kultuurilis-ajaloolisest perspektiivist. Võgotski pakub välja ja tõestab mõned seisukohad, mis on üsna tähtsad ka tänapäeva psühholoogia jaoks. Esimene seisukoht on seotud kujutlusvõime ja loovustegevusega.

Argikasutuses nimetatakse kujutluseks või fantaasiaks kõike seda, mis pole reaalne, ei vasta tegelikkusele, ja millel ei saa seega olla mingit tõsist praktilist tähendust. Tegelikult avaldub kujutlusvõime kui igasuguse loovusliku tegevuse alus kultuuri kõigis valdkondades ning teeb võimalikuks kunstilise, teadusliku ja tehnilise loomingu. Selles mõttes on võrreldes loodusega kõik see, mis meid ümbritseb ja mis on tehtud inimkätega - kogu kultuurimaailm - inimese kujutlusvõime ja loovuse resultaat ja rajaneb kujutlusvõimel. (Lk 12)

Samuti võib lisada, et argikasutuses on arusaam loovusest tihtilugu seotud ainult loovusega selle kõrgemas tähenduses (kunstiline loovus), kuid Võgotski käsitleb mõisteid loovus ja ka kultuur laiemas perspektiivis.

Teine seisukoht puudutab loovuse ja kujutlusvõime seost inimese kogemusega. Võgotski toob esile selle, mida ta nimetab esimeseks seaduseks, millele kujutlusvõime allub.

[...] kujutlusvõime loovuslik tegevus on otseselt sõltuv inimese varasema kogemuse rikkusest ja mitmekesisusest, sest see kogemus annab materjali, millest luuakse fantaasia konstruktsioonid. Mida rikkam on inimese kogemus, seda rohkem on materjali, mis seisab tema kujutlusvõime käsutuses. Seepärast ongi lapse kujutlusvõime täiskasvanu omast vaesem, see tuleneb lapse väiksemast kogemusest. (Lk 20)

Seega pole kujutlusvõime ja fantaasia juured mitte irreaalses maailmas, vaid need on puhtalt tegelikkuse produktid. 
Mida rohkem laps näeb, kuuleb või läbi elab, seda rohkem ta teab ja omandab, seda rohkem valdab ta tegelikkuse elemente, seda olulisem ja produktiivsem (teiste tingimuste võrdsuse juures) on tema kujutlusvõime. (Lk 21)

Võgotski asetab rõhu ka teisele väga olulisele aspektile, nimelt võõrale ehk sotsiaalsele kogemusele. Just sotsiaalne kogemus on see, mis soodustab lapse kujutlusvõimet ja fantaasiat - „toimib justkui võõra juhendi alusel, ainult tänu sellele on võimalik tulemus, kus kujutlus ühtib tegelikkusega“ (lk 23).

Kolmas seisukoht, millest autor lähtub või mida ta soovib tõestada, on seotud fantaasia ja kujutlustegevuse produktide mõjuga lapse või nooruki käitumisele. Tõepoolest, nii lastel kui ka täiskasvanutel on kujutlusvõime, kuid selle mõju käitumisele on erinev. Võgotski kirjeldab seda järgmiselt.

Laps võib ette kujutada märksa vähem kui täiskasvanu, aga ta usaldab oma kujutlusi rohkem ja kontrollib neid vähem. Seepärast on tema kujutlused, erinevalt täiskasvanust, argitähenduses tõelised väljamõeldised ja seega vähem tõepärased. Kuid lapsel pole vähem mitte ainult kogemuslikku materjali, millele ta oma kujutlusi ehitab, täiskasvanust palju vaesem on ka sellele materjalile toetuv kujutluse kombinatsioonide iseloom. (Lk 46)

Võgotski juhib tähelepanu ka sellele, et laste looming on tugevasti seotud mänguga. Esitletava raamatu teine osa on Võgotski artikli (kunagise loengu) „Mäng ja selle osa lapse psüühilises arengus" tõlge. Kui jutt läheb lapse mängule, siis on kombeks seda alustada kuulsa füüsiku Albert Einsteini sõnadega, mille kohaselt on aatomist arusaamine lapsemäng võrreldes arusaamisega, mis on lapse mäng. Lapse mängu teooriaid on palju, kuid huvilised võivad pöörduda kokkuvõtliku, ent informatiivse ülevaate saamiseks raamatu „Õppimine ja õpetamine koolieelses eas ${ }^{\text {“2 }}$ poole.

Oma igapäevases elus kuuleme tihtilugu, kui lapsevanemad torsakalt ja kohati ka kahetsusega ütlevad lapsele: „Jälle sa mängid! Millal sa ükskord täiskasvanuks saad?" Lapse mängu teke on Võgotski järgi seotud realiseerimatute tungidega, sest oma varases lapseeas tahab laps kohe lahendada probleeme ja rahuldada vajadusi, nende tegevuste edasilükkamine on lapse jaoks üsna raske.

[...] näib, et kui eelkoolieas poleks kohe rahuldamatute vajaduste tekkimist, siis poleks meil ka mängu. (Lk 135)

Vt A. Niilo ja E. Kikase peatükki „Mäng“ raamatus „Õppimine ja õpetamine koolieelses eas“ (2008). See raamat on suurepärane abivahend nii tudengitele kui ka neile, kes tunnevad huvi arengupsühholoogia vastu. Tugev nõudlus selle raamatu järele raamatukogudes võiks olla ka kõva argument raamatu kordustrükiks. Sama teemat käsitletakse ka põhjapanevas A. Saare raamatus „Laps ja mäng“ (1997). 
Just selliste realiseerimatute tungide olemasolu teebki mängu võimalikuks, kuid mängu kaudu ei täitu mitte lapse üksikud soovid, vaid „üldistatud afektidele rajanevad soovid“ (lk 138). Mänguga loob laps näilise situatsiooni, aga mida tähendab lapse käitumine selles situatsioonis? See on käitumine kindlate reeglite järgi, ja just siin jõuab Võgotski oma tähtsa postulaadi juurde: „See, mis elus on lapse jaoks märkamatu, muutub mängus käitumisreegliks" (lk 142). Seega ei saa laps mängides käituda ilma reegliteta, samas "näiline situatsioon vabastab lapse situatsioonilisest seotusest“ (lk 145) ja laps hakkabki tegutsema sõltumata sellest, mida ta näeb.

Tegutsemine, laiemas mõttes käitumine näilises situatsioonis (olukorras, mis pole nähtav) viib selleni, et laps suudab juhinduda selle „olukorra tähendusest" (vn смысл ситуации), aga mitte vahetust tajust. Lapse jaoks on üpris raske eraldada mõtet esemest, kuid mäng on omapärane üleminekuvorm, mis kergendab seda.

Sel momendil, kui kepp, st ese muutub algimpulsiks hobuse tähenduse lahutamisel reaalsest hobusest, sellel kriitilisel momendil muutub täielikult üks põhilisi psüühilisi struktuure, mis määrab suhtumist tegelikusesse. [...] Mängus opereerib laps esemete kui asjadega, millel on tähendus, opereerib esemeid tähistavate sõnade tähendusega, seetõttu toimub mängus sõna vabanemine esemest [...] (Lk 148-151)

Mäng on seega küll näilik olukord, kuid kõik tegevused on ainulaadselt tegelikud. Erinevalt otsesest impulsist on mäng tegutsemine. Mängureeglid piiravad võimalust saada kõike ja kohe (naudingut, tulemust, auhinda jms) ning reeglite järgimine mängus annab suurema naudingu kui otsene, esialgne impulss. Võgotski sõnul „mängus nutab laps patsiendi rollis, kuid mängijana teeb see talle rõõmu [...] Seega on mängu oluliseks tunnuseks reegel, mis muutub afektiks" (lk 153-154).

Peale eelnimetatute on Võgotski mängu kontseptsioonil veel üks tähtis tunnus, milleta oleks Võgotski käsitlus ebatäielik: mäng loob lapse „lähima arengu tsooni“. Lähima arengu tsoon on vahemaa lapse tegeliku ja potentsiaalse arenguastme vahel. Laps saavutab selle kas täiskasvanu abil, kes juhendab teda, või tegevuses võimekamate eakaaslastega, kelle juhendamisel saavutab ta homme selle, mida ta veel täna ei oska - „mängus laps justkui püüaks hüpata kõrgemale oma tavalise käitumise tasemest“ (lk 158-159). Tänu koostööle targema ja kogenuma koostööpartneriga jõuab laps oma lähima arengu tsoonis selleni, milleni ta üksi poleks jõudnud, seega on teiste inimeste juuresolek ja koostöö lapse arengu seisukohalt ülitähtsad (seda on vaja meeles pidada eriti ajastul, kus igasuguste gadget'ide ülekaal teeb inimese küll tänapäevasemaks, kuid samas võorastab ühe inimese teisest). 
Võib arvata, et raamat „Laste loovus ja kujutlusvõime“ leiab oma lugeja, kes hakkab seda kasutama nii oma töös kui ka igapäevases tegevuses. Samuti on sellest allikast suur kasu üliõpilasele ja õppejõule, eriti kasvatusteaduste ja psühholoogia valdkonnas. 